\title{
Metabolic Changes in Epileptic Patients Experiencing Seizure During Fasting in the Ramadan
}

\author{
Ramazan Ayında Oruç Süresince Nöbeł Geçiren Epileptik Hastalardaki \\ Metabolik Değişiklikler
}

\author{
Emine AKINCI, Hayri RAMADAN, Yasemin YILMAZ AYDIN, Handan ÇifTÇi, Figen COŞKUN \\ Department of Emergency Medicine, Ankara Research and Training Hospital, Ankara
}

\begin{abstract}
SUMMARY
Objectives

Fasting during the month of Ramadan can lead to changes in the electrolyte balance and hematocrit. We compared the metabolic states of epilepsy patients who presented to the emergency department following a seizure, either when fasting during the month of Ramadan or during non-fasting periods.
\end{abstract}

\section{Methods}

The study included 20 consecutive patients who experienced an epileptic seizure while fasting during the month of Ramadan in 2010 and 20 additional patients who experienced a seizure while not fasting. All patients were seen at the emergency room in the Ankara Training and Research Hospital. Venous blood gas, complete blood count, kidney function tests, sodium, potassium, chloride, blood glucose and a full urinalysis were measured in all patients. The patients were followed for approximately 12 hours.

\section{Results}

No statistically significant differences were observed between the fasting group and control group in terms of the average age of the patients and gender distribution. No significant differences were observed in the blood $\mathrm{pH}$, anion gap, osmolarity or base deficit $(p>0.05)$. The ketone level was significantly higher in the urine of the fasting group $(p<0.047)$.

\section{Conclusions}

There was no significant difference found in metabolic state of fasting epilepsy patients and the control group. The only significant difference was the higher level of ketones in fasting epilepsy patients compared to the control group.

Key words: Epilepsy; metabolic changes; Ramadan.

\section{ÖZET}

Amaç

Ramazan ayında oruç tutmak, elektrolit imbalansında ve hematokrit dengesinde değişikliklere neden olabilir. Bu çalışmamızda bilinen epilepsisi olup, Ramazan ayında oruç tutan ve epileptik nöbet geçiren hastalarla, bilinen epilepsisi olan acil servise nöbet geçirme nedeniyle gelen ancak oruç tutmayan hastaların metabolik durumlarını karşılaştırmayı amaçladık.

\section{Gereç ve Yöntem}

Ankara Eğitim ve Araştırma Hastanesi Acil Servisine 2010 yılı ramazan ayında oruç tutan ve epilepsi nöbeti geçiren 20 hasta ve ramazan ayı sonrasında nöbet geçirdikten sonra gelen 20 ardışık hasta çalışmaya alındı. Hastalardan venöz kan gazı, tam kan sayımı, böbrek fonksiyon testleri, sodyum, potasyum, klor, kan şekeri, tam idrar tetkikleri istendi. Hastalar yaklaşık 12 saat süre ile takip edildi.

\section{Bulgular}

Oruç tutan grup ile kontrol grubu arasında yaş ortalamaları ve cinsiyet dağılımı yönünden istatistiksel olarak anlamlı farklılık görülmemiştir. Oruç tutan grup ile kontrol grubu arasında kan $\mathrm{pH}, \mathrm{HCO}_{3^{\prime}}$ anyon açığı, osmolarite ve baz açığı artışı yönünden anlamlı farklılık görülmemiştir ( $p>0.05$ ). Idrarda keton yönünden gruplar arasında anlamlı fark olup oruç tutan grupta idrarda keton düzeyi daha yüksekti $(p<0.047)$.

\section{Sonuç}

Oruç tutan epileptik hasta grubu ile kontrol grubu arasında metabolik açıdan belirgin fark bulunamamıştır. Çalışmamıza göre sadece oruç tutan epileptik hastaların keton düzeyleri tutmayanlara oranla daha yüksektir.

Anahtar sözcükler: Epilepsi; metabolik değişiklikler; Ramazan ayı. 


\section{Introduction}

More than one billion Muslims fast for one month (Ramadan) each year, for periods of between 12 to 18 hours per day depending on the time of year that Ramadan occurs, with the summer months having the longest fasting periods. Muslims observing the fast must not only abstain from eating and drinking, but also from taking oral medications, smoking, as well as receiving intravenous fluids and nutrients. ${ }^{[1]}$ The quantity of fluid and food intake also changes during Ramadan. Volume deficit and dehydration can occur, especially in the long summer days. Patients with any illness and those on medications have to adjust their treatments to comply with Ramadan. Thus, patients' medication schedules also change..$^{[2]}$

Previous studies have explored the effects of fasting during Ramadan on the gastrointestinal system, coronary heart disease, diabetes mellitus and circadian rhythms ${ }^{[3-5]}$ Accordingly, some publications reported that there are adverse affects of fasting during Ramadan on the electrolyte balance and hematocrit level. ${ }^{[1]}$

In our study, we compared the metabolic state of known epilepsy patients who suffered a seizure during Ramadan or during a non-fasting period (the control group).

\section{Materials and Methods}

The study included 20 consecutive patients with known epilepsy who had a seizure while fasting during Ramadan 2010 and 20 additional patients who experienced a seizure following Ramadan. All patients were seen at the emergency room of the Ankara Training and Research Hospital.

\section{Inclusion Criteria}

- Patients formerly diagnosed with epilepsy

- Patients fasting during Ramadan and experiencing a seizure

\section{Exclusion Criteria}

- First time seizures

- Pregnant women

- Those under 18 years old

- Epileptic patients who do not fast during Ramadan

- Those who were not compliant with their drug regime

- Those who did not consent to participate were excluded from the study.

Patients who presented to the emergency room while suffering from a seizure were placed in an observation room after their vital signs were taken. An $18 \mathrm{G} \mathrm{IV} \mathrm{line} \mathrm{was} \mathrm{started.}$ Diazepam $5 \mathrm{mg}$ was kept available in the injector for use should the seizure reoccur. Venous blood gas, a complete blood count, kidney function tests, sodium, potassium, chloride, blood glucose and a full urinalysis were measured in all patients. Laboratory measurements were made using LIASION, ACL TOP and Roche Cobas 221 devices. The patients who did not experience an additional seizure were followed for a period of approximately 12 hours.

\section{Statistics}

Data analysis was performed using SPSS (version 11.5 for Windows). The Shapiro-Wilk test was used to determine whether continuous variables were normally distributed. Descriptive statistics are listed in this paper using average \pm standard deviation or median (minimum-maximum) for continuous variables and as means of number of the event and (\%) for nominal variables. Student's $t$ test was used to determine if a significant difference was present between group means and the Mann-Whitney $U$ test was used to test for significance differences between group median values. Nominal variables were evaluated using Pearson's chisquare test or Fisher's exact chi-square test. A p value $<0.05$ was considered statistically significant.

\section{Results}

It was determined that the fasting group had a clear change in their drug regime. The patients stated that they took their drugs at the pre-dawn meal of sahur or at the fast-breaking dinner, iftar. All patients in the fasting group stated that their regular sleep routines had changed during Ramadan because of sahur and that they slept approximately 2 hours less during this period.

No significant differences were found between the study and control group in terms of average age or gender distribution $(p=0.915$ and $p=0.525)$. No significant inter-group differences were found in terms of blood glucose, urea, creatine, sodium, potassium and chloride levels $(p>0.05)$ (Table 1$)$.

No significant inter-group differences were observed in the blood $\mathrm{pH}$, bicarbonate, anion gap, osmolarity or the rate of patients with increased base deficit ( $p>0.05$ ). It was found that the ketone level was significantly higher in the urine of the fasting group. The mean ketone level of the fasting group was $50 \mathrm{mg} / \mathrm{dl}(+)$ and was slightly higher than the control group $(p<0.047)$ (Table 2).

When comparing the clinical and biochemical status of the two groups, there were significant inter-group differences in terms of the anion gap and urinary ketones. It was more common for the control group to have an abnormal anion gap and the fasting group to have elevated urinary ketones $(p=0.003$ and $p<0.047$, respectively) (Table 3 ). 
Table 1. Demographic and biochemical characteristics of the fasting and control groups

\begin{tabular}{lccc}
\hline Variables & Fasting group & Control group & p \\
\hline Age & $34.5 \pm 14.6$ & $35.9 \pm 14.7$ & 0.915 \\
Gender (F/M) & $8 / 12$ & $10 / 10$ & 0.525 \\
Blood glucose (Mg/dl) & $105.0(84-273)$ & $122.5(90-262)$ & 0.108 \\
Urea (Mg/dl) & $27.2 \pm 9.7$ & $29.5 \pm 11.2$ & 0.501 \\
Creatine (Mg/dl) & $0.94 \pm 0.26$ & $0.96 \pm 0.22$ & 0.846 \\
Sodium (mEq/L) & $138.5(121-141)$ & $136(121-143)$ & 0.134 \\
Potassium (mEq/L) & $4.0 \pm 0.41$ & $3.9 \pm 0.44$ & 0.260 \\
Chlor (mEq/L) & $102.1 \pm 5.3$ & $101.0 \pm 4.8$ & 0.478 \\
\hline F: Female; M:Male. & & &
\end{tabular}

\section{Discussion}

Epilepsy is an illness in which the patient experiences seizures due to the synchronization and abnormal electrical behaviour of all or part of the cerebral neurons. Epileptic seizures occur when balance between the inhibition and excitation of the central nervous system is disrupted. ${ }^{[6]}$ In order to prevent epileptic seizures, it is suggested that patients live a regular life, avoid alcoholic drinks and follow their drug therapy correctly. In addition to medical treatment, it is recommended that patients should adopt a regular sleep pattern and get 7-8 hours of sleep a night and avoid stress. Many of the parameters mentioned above are disrupted during the month of Ramadan. Uremia, hypernatremia, hyponatremia, hypocalcemia and disturbances in amino acid and vitamin metabolism are all known to cause epileptic seizures. ${ }^{[7,8]} \mathrm{Al}-$ hazmi et al. ${ }^{[9]}$ reported that there were no significant changes in the sodium and potassium values of fasting patients. They also reported that the sodium, potassium and glucose levels in fasting epilepsy patients were within normal limits. ${ }^{[10]}$ In our study, we did not find a significant difference in the blood glucose, urea, creatine, sodium, potassium and chloride levels between fasting patients and the control group.
A significant change in drug regime in fasting patients was noted. The patients stated that they took drugs in the pre-dawn meal of suhoor or the fast-breaking dinner, iftar. Changes in the dosage and timing of drug therapy are important causes of increased seizure frequency among epileptic patients. Gomceli et al. ${ }^{[11]}$ showed that there were changes in epilepsy frequency among fasting epilepsy patients. They also stated that the seizure frequency increased during fasting, despite no change in drug regime, and that this increased incidence might be due to emotional stress and fatigue, either separately or in combination. In contrast, Khattab et al. reported that seizure frequency did not increase, even in patients who cut back from 3 doses of carbamazepine to 2 doses during the fast. It was found that there was no significant reduction in the serum carbamazepine levels, potentially due to its long half-life. ${ }^{[10]}$

Several studies have reported that Ramadan fasting causes changes in serum glucose levels. ${ }^{[12-14]}$ If hypoglycemia is present during Ramadan due to reduced food intake, it may evoke epileptic seizures. Many researchers have confirmed that lipid, carbohydrate, protein and hormone metabolism changes occur during fasting. ${ }^{[15]}$ All of these metabolic chang-

Table 2. Clinical features of the fasting and control groups

\begin{tabular}{lccc}
\hline Variables & Fasting group & Control group & p \\
\hline Blood $(\mathrm{pH})$ & $7.35(7.02-7.46)$ & $7.37(7.12-7.42)$ & 0.341 \\
$\mathrm{HCO}_{3}(\mathrm{mmol} / \mathrm{L})$ & $21.6(13.2-25.3)$ & $22.5(16.5-26.8)$ & 0.314 \\
Anion gap $(\mathrm{mmol} / \mathrm{L})$ & $13.7 \pm 3.50$ & $11.5 \pm 5.46$ & 0.150 \\
Base deficit $(\mathrm{mmol} / \mathrm{L})$ & $12(60.0 \%)$ & $6(30.0 \%)$ & 0.057 \\
Osmolarity & $293(255-304)$ & $290(262-311)$ & 0.659 \\
pH in the urine & $7(5-8)$ & $6(5-7)$ & 0.033 \\
\hline
\end{tabular}


Table 3. The prevalence of biochemical parameters outside the normal range between the groups

\begin{tabular}{lccc}
\hline Variables & Fasting group (n) & Control group (n) & p \\
\hline Urea $>55(\mathrm{mg} / \mathrm{dl})$ & $2(10.0 \%)$ & $3(15.0 \%)$ & 1.000 \\
Creatine $>1.1(\mathrm{mg} / \mathrm{dl})$ & $5(25.0 \%)$ & $3(15.0 \%)$ & 0.695 \\
Sodium $>145(\mathrm{mg} / \mathrm{dl})$ & $4(20.0 \%)$ & $7(35.0 \%)$ & 0.288 \\
Potassium $>5.5(\mathrm{mg} / \mathrm{dl})$ & $1(5.0 \%)$ & $2(10.0 \%)$ & 1.000 \\
Chlorine $>110(\mathrm{mg} / \mathrm{dl})$ & $3(15.0 \%)$ & $3(15.0 \%)$ & 1.000 \\
Urine $\mathrm{pH}<4.5$ & $10(50.0 \%)$ & $5(25.0 \%)$ & 0.102 \\
HCO $<22(\mathrm{mmol} / \mathrm{L})$ & $14(70.0 \%)$ & $12(60.0 \%)$ & 0.507 \\
Anion gap $>15(\mathrm{mmol} / \mathrm{L})$ & $3(15.0 \%)$ & $12(60.0 \%)$ & 0.003 \\
Osmolarity $>295$ & $9(45.0 \%)$ & $10(50.0 \%)$ & 0.752 \\
Ketone in the urine $>50(\mathrm{mg} / \mathrm{dl})$ & $5(25.0 \%)$ & $0(0 \%)$ & 0.0047 \\
\hline
\end{tabular}

\section{References}

1. Abdalla $A H$, Shaheen FA, Rassoul Z, Owda AK, Popovich WF, Mousa DH, et al. Effect of Ramadan fasting on Moslem kidney transplant recipients. Am J Nephrol 1998;18:101-4.

2. Aadil N, Houti IE, Moussamih S. Drug intake during Ramadan. BMJ 2004;329:778-82.

3. Ozkan S, Durukan P, Akdur O, Vardar A, Torun E, Ikizceli I. Does Ramadan fasting increase acute upper gastrointestinal haemorrhage? J Int Med Res 2009;37:1988-93.

4. Hui E, Devendra D. Diabetes and fasting during Ramadan. Diabetes Metab Res Rev 2010;26:606-10.

5. Al Suwaidi J, Bener A, Suliman

es may evoke epileptic seizures. In our study, the ketone levels were significantly higher in the urine of the fasting group $(p<0.0047)$. The presence of ketonuria in the absence of hypoglycemia is an indicator of a serious catabolic process in fasting patients. Prolonged hunger in epilepsy patients can lead to catabolic processes that may trigger seizures. However, prolonged hunger has also been used to treat epilepsy. Ketogenic diets have been used for more than 100 years to prevent seizures in certain types of epilepsy. Prolonged diets with only water or very limited carbohydrate intake were used to prevent seizures in children in the 1920's and positive results were achieved. ${ }^{[16]}$ Today, even though the exact mechanism of effect is not known, ketogenic diets are still used in children with refractory epilepsy. ${ }^{[17]}$

\section{Limitations}

One of the limitations of our study was the climate that the study was conducted in. The average temperature during the month of Ramadan (August 11 - September 9 ) was $34^{\circ} \mathrm{C}$ whereas it was $32^{\circ} \mathrm{C}$ after Ramadan (September 15-October $15)$. The difference in the average temperature may contribute to the higher levels of ketones found in fasting patients during the month of Ramadan.

\section{Conclusion}

There was no significant difference found in the metabolic states of fasting epilepsy patients and the control group. The only significant difference was the higher levels of ketones in fasting epilepsy patients compared to the non-fasting group.

\section{Conflict of Interest}

The authors declare that there is no potential conflicts of interest.
A, Hajar R, Salam AM, Numan MT, et al. A population based study of Ramadan fasting and acute coronary syndromes. Heart 2004;90:695-6.

6. Oztaş B. Konvulsiyonların etyopatogenezine nöron düzeyinde yaklaşım. Nöropsikiyatri Arşivi 1986;XXIII:1-2.

7. Kumar PJ, Clark ML. Epilepsy. In: Kumar PJ, Clark ML, Jackson WF, editors. Clinical medicine: a textbook for medical students and doctors. London and Philadelphia: Baillière Tindall; 1987. p. 822-7.

8. Feldman RG. Management of underlying causes and precipitating factors of epilepsy. In: Browne TR, Feldman RG, editors. Epilepsy diagnosis and management. Toronto: Little Brown; 1983. p. 129-38.

9. Alhazmi MA, Alfaleh FZ, Almotleh FA. Effect of Ramadan fasting on the values of hematological and biochemical parameters. Saudi Med J 1987;8:171-9.

10. Elham Khattab, Isam Hamo Mahmood, Emad Thanoon Abduljabbar. Can epileptic patients on carbamazepine safely fast Ramadan? JIMA 2008;40:156-60.

11. Gomceli YB, Kutlu G, Cavdar L, Inan LE. Does the seizure frequency increase in Ramadan? Seizure 2008;17:671-6.

12. Azizi F, Rasouli HA. Serum glucose, bilirubin, calcium, phosphorus, protein and albumin concentrations during Ramadan. Med J IR Iran 1987;1:38-41.

13. Davidson JC. Muslims, Ramadan, and diabetes mellitus. $\mathrm{Br}$ Med J 1979;2:1511-2.

14. Iraki L, Bogdan A, Hakkou F, Amrani N, Abkari A, Touitou Y. Ramadan diet restrictions modify the circadian time structure in humans. A study on plasma gastrin, insulin, glucose, and calcium and on gastric pH. J Clin Endocrinol Metab 1997;82:1261-73.

15. Hallak MH, Nomani MZ. Body weight loss and changes in blood lipid levels in normal men on hypocaloric diets during Ramadan fasting. Am J Clin Nutr 1988;48:1197-210.

16. Woodyat RT. Objects and method of diet adjustment in diabetes. Arch Intern Med 1921;28:125-41.

17. Wheless JW. History of the ketogenic diet. Epilepsia 2008;49:3-5. 